\title{
Hydrographical Observations during a Red Tide with Fish Mortalities at Masirah Island, Oman
}

\author{
Saud S. Al Busaidi ${ }^{* 1}$, Khalfan M. Al Rashdi², \\ Hamed M. Al Gheilani' ${ }^{1}$ and Shehla Amer ${ }^{3}$
}

${ }^{1}$ Ministry of Fisheries Wealth, Marine Science \& Fisheries Center, Muscat, Oman

${ }^{2}$ Ministry of Fisheries Wealth, Aquaculture Center, Muscat, Oman

${ }^{3}$ Nizwa University, Nizwa, Oman

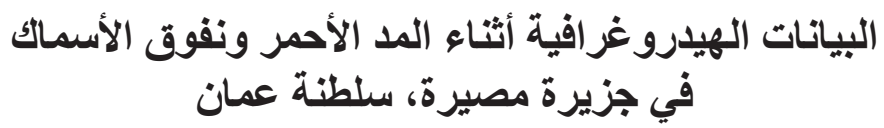

سعود البوسعيدي، خلفان الراشدي، حمد الغيلاني، شهلاء عامر

الخلاصنة: يمكن أن يكون لازدهار الطحالب الضارة تأثثر مهم في توزيع وحياة الأسماك واللافقاريات في المياه الساحلية، وبالتالي في الاقتصاد المحلي أينما كان الصيد من الأنشطة المهمة. في أكتوبر من عام ه م. . بم، اصطبغت المياه في شرق جزيرة مصبرة باللون البني/ البرتقالي بسبب الازدهار الكبير للطحالب مما أدى إلى نفوق الكثيرمن الأسماك. وبيتنت صور الأقمار الصناعية وجود تيار ات بحرية صاعدة (انبثاقات) باردة قبيل حدوث ظاهرة الازدهار ونفوق الأسماك، ثم أعقبها ارتفاع تدريجي في درجة حرارة المياه متز امنا مع بداية حدوث الظاهرة. قراءات الأعماق للأكسجين الذائب، ودرجات الحرارة، و الملوحة، ومعدل الحموضة ودة التي أخذت يوم 9 ا اكتوبر (أثناء حدوث الظاهرة) بينت بجلاء وجود انحدار حراري على عمث حو الي 0 (متر ا، بينما قلت كمية الأكسجين

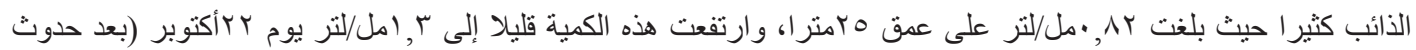
الظاهرة).وكانت هناك اسماك قاعية هامة اقتصاديا ضمن الأسماك النافقة. لم يكتشف وجود تلوث بكتيري في عينات الأسماك كما لم يتم تسجيل أي تسم بين المستهلكين. و أظهر تحليل عينات العو الق البحرية وجود ازدهار لثنائيات الأسو اط البحرية إضافة إلى ازدهار الطحالب الخضر اء-الزرقاء.

ABSTRACT: Harmful Algal Blooms (HABs) can have a significant impact on the distribution and survival of coastal fishes and invertebrates, and consequently they can affect local economies where fishing is an important activity. In October 2005 , extensive algal blooms with brownish/orange discoloured water and fish mortalities were observed east of Masirah Island. Satellite images revealed cooler upwelled surface water along a broad front just prior to the event, followed by a gradual warming period coinciding with the mortalities. Depth profiles of dissolved oxygen (DO), temperature, salinity and $\mathrm{pH}$ taken on $19^{\text {th }}$ October (during the fish mortality event) showed a pronounced thermocline at $\sim 15 \mathrm{~m}$ depth and minimum DO of 0.82 $\mathrm{ml} / \mathrm{L}$ at $25 \mathrm{~m}$ depth, and a slight improvement in DO to $1.3 \mathrm{ml} / \mathrm{L}$ was measured on $22^{\text {nd }}$ October (after the event). Demersal fishes of several families were prominent among mortalities. No bacterial infestation was found in fish samples and no human poisoning was reported. Planktological data showed that marine dinoflagellates Noctiluca scintillans and Prorocentrum micans and toxic blooms of cyanobacterium Trichodesmium erythraeum were present.

Keywords: Red tide, upwelling, fish mortalities, Arabian Sea, Oman.

\section{Introduction}

Official documentation of red tide events along the coast of Oman began in 1978, and fish, mollusk and crustacean mortalities associated with these events have often been reported in the region (Claereboudt et al. 2001). The causes of mortalities are not always clear - these may be the result of harmful algal blooms (HABs) dominated by toxic dinoflagellates (e.g. Peridinium, Dinophysis, Prorocentrum spp.) which may poison fish or other organisms when they release their toxins, or alternatively the result of oxygen depletion in confined areas during the bacterial oxidation of collapsed blooms. Claereboudt et al. (2001) suggested that mortalities during a red tide (mainly the non-toxic diatom Coscinodiscus spp.) in the Gulf of Oman in 2000 were driven by oxygen 


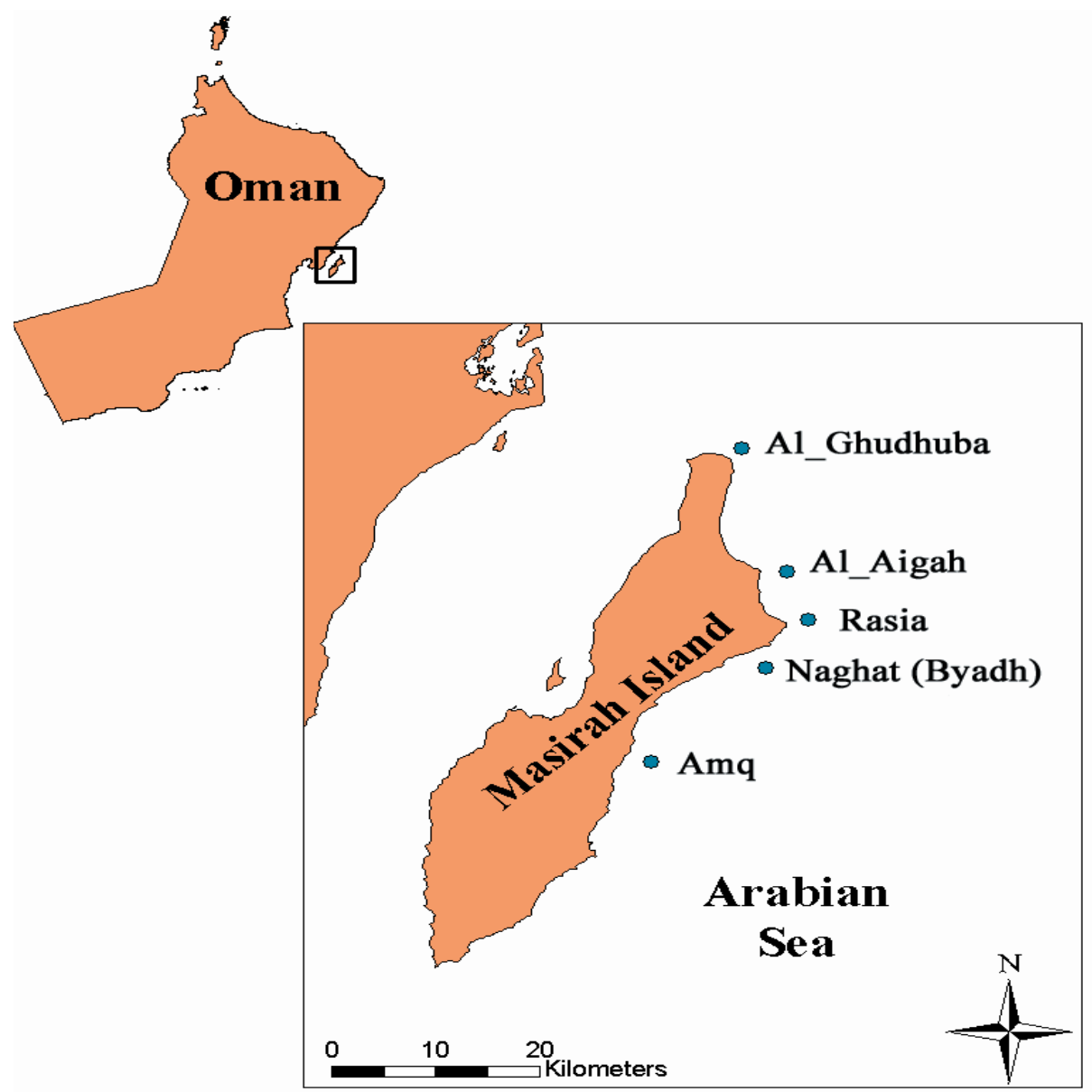

Figure 1. Study sites in Masirah Island, Arabian sea.

depletion below the thermocline and not by toxicity. Other red tide events in Oman have been attributed to Noctiluca blooms (Thangaraja et al., 2000), which are known to affect the water quality by depleting the oxygen in seawater or by contributing to higher levels of ammonia (Okaichi and Nishio, 1976).

Massive fish and invertebrate kills were reported along the coast of Masirah Island around $13^{\text {th }}$ October 2005 and mortalities continued up to at least the $19^{\text {th }}$ of the month. During this period fishers noted that some fish species were lethargic, and could be caught easier than usual. Seawater in the immediate area was discoloured, brown and orange, suggesting a large phytoplankton bloom. SST, water temperature, dissolved oxygen, $\mathrm{pH}$ and salinity were measured from the surface to $30 \mathrm{~m}$ depth during and after the event, and water samples analysed to identify the predominant algal groups. Affected fish were identified to family level. Based on these observations, we suggest a possible cause for the mortality event.

\section{Methods}

Phytoplankton samples were taken from five sites along the eastern coast of Masirah Island (a $45 \mathrm{~km}$ stretch) on October $18^{\text {th }}$ and $19^{\text {th }}$ (during the fish kill) and on October $22^{\text {nd }}$ (thereafter). From north to south, the sites were Al Ghudhuba $\left(20^{\circ} 42^{\prime} \mathrm{N}\right.$; $\left.58^{\circ} 55^{\prime} 22 \mathrm{E}\right) \mathrm{Al}-$ Aijah $\left(20^{\circ} 42^{\prime} \mathrm{N}\right.$; $58^{\circ} 55^{\prime} 22 \mathrm{E}$ and $20^{\circ} 34^{\prime} 57 \mathrm{~N}$; 58 $8^{\circ} 57^{\prime} 43$ E), Rasiyah $\left(20^{\circ} 31^{\prime} 01 \mathrm{~N} ; 58^{\circ} 59^{\prime} 29 \mathrm{E}\right.$ and $20^{\circ} 31^{\prime} 24 \mathrm{~N}$; $\left.59^{\circ} 00^{\prime} 29 \mathrm{E}\right)$, Naghat $\left(20^{\circ} 27^{\prime} 41 \mathrm{~N} ; 58^{\circ} 58^{\prime} 03 \mathrm{E}\right)$ and Amq $\left(20^{\circ} 22^{\prime} 22 \mathrm{~N}\right.$; 58 $\left.54^{\prime} 58 \mathrm{E}\right)$ (Fig. 1). Phytoplankton samples were collected using a Bongo net $(80 \mu \mathrm{m}$ 
mesh size) and Niskin bottles, and were preserved with formaldehyde (4\%, Velikova and Larsen, 1999), and studied under a microscope, without staining.

Samples were taken from all five sites on $18^{\text {th }}$ and $19^{\text {th }}$ October, and again at two badly affected sites at Al-Aijah ( $2^{\text {nd }}$ position) and Rasiyah on $22^{\text {nd }}$ October. Water quality parameters $\mathrm{pH}$, temperature, salinity and dissolved oxygen (DO), were measured from the surface and at $5 \mathrm{~m}$ depth intervals up to 30 $m$ depth using Hydrolab (Data Sonde 4a). SST of the Gulf of Oman and Arabian Sea between Ras al Hadd and Salalah (including Masirah Island) was available for the $26^{\text {th }}$ of September, and the $3^{\text {rd }}, 12^{\text {th }}$ and $13^{\text {th }}$ of October from NOAA-14 AVHRR (Advance Very High Resolution Radiometer) imagery.

Dead fish were identified to family level whenever possible, and bacteriological examination of the frozen samples was done in a specialised laboratory (Bacteriology Section, Department of Laboratories, Ministry of Health). Samples were analyzed for the presence of Colioformis, Esherichia coli, Salmonella, Shigella, Vibrios, Staphylococcus aureus, Cyanobacteria, Bacillus cereus, Clostridium and Listeria monocytogenes.

\section{Results and Discussion}

Phytoplankton samples showed the presence of Noctiluca scintillans, (Fig. 2), Prorocentrum micans (Fig. 3) and Trichodesmium erythraeum (Fig. 4), whilst the dinoflagellate $P$. micans was the dominant species. Blooms of P. micans generally occur in zones receiving high solar energy and anthropogenic inputs, which are rich in nutrients and dissolved organic matter (Anderson et al., 2002; Subba Rao et al., 1995). In several parts of the world, fish kills have been attributed to low dissolved oxygen levels generated by high biomass blooms and not necessarily due to toxicity. For example, from 1980-1989, at least 50\% of fish killed in the Gulf of Mexico and 69\% in the South Atlantic, USA, were attributed to low dissolved oxygen (Lowe et al., 1991). Similarly, low DO levels have also been the most popular cause for the fish mortality in Oman. In most cases the dominant red tide causing species in the Gulf of Oman is Noctiluca scintillans (Thangaraja et al., 2000). Noctiluca scintillans is also non-toxic but can reduce water quality by depleting oxygen and raising ammonia levels (Okaichi and Nishio, 1976).
The identification of the marine cyanobacterium Trichodesmium erythraeum was less straightforward than that of diatoms and dinoflagellates because of the lack of distinct and unique morphological characteristics. Nevertheless, our identification was based on the morphological description of Post et al. (2002), who described colonies with trichomes arranged in parallel bundles or rafts (tufts) floating on the surface in the Gulf of Aqaba. An extensive surface bloom of T. erythraeum was also previously observed in the central basin of the Arabian Sea during the Spring Intermonsoon of 1995 (Capone et al., 2000), a period of calm winds similar to the conditions at Masirah Island in October 2005. Trichodesmium erythraeum is capable of utilizing ammonia and urea (Ohki et al., 1991), and it does contain toxic, water-soluble material which is the progenitor of major toxins carried by some ciguateric fish. Release of these water-soluble toxins into ambient seawater may constitute a health hazard for humans (Endean et al., 1993).

The satellite image from $26^{\text {th }}$ September shows a broad front of cooler surface water (approx. $20^{\circ} \mathrm{C}$ ) stretching alongshore from Ras al Hadd to Salalah, and enveloping Masirah Island (Fig. 5a). By $3^{\text {rd }}$ October, upwelling have intensified to the south of Masirah Island $\left(15-17^{\circ} \mathrm{C}\right)$, with warming surface waters towards the north of the island (Fig. 5b). A narrow band of cooler coastal waters (around $20-21^{\circ} \mathrm{C}$ ) is apparent along the east coast of Masirah Island and northwards to Ras Al Hadd on the $12^{\text {th }}$ of October (Fig. 5c), but by $13^{\text {th }}$ October temperatures seem to have increased along the entire coastline (Fig. 5d). These images suggest that upwelling events occurred over a period of at least 2 weeks before fish kills were reported at Masirah Island, but the mortalities themselves, or at least the reports thereof, coincided with warmer surface temperatures. Unfortunately, no earlier images were available to show the SST conditions leading up to the $26^{\text {th }}$ of September, nor were images available for the period of most reported mortalities after $13^{\text {th }}$ October.

A pronounced thermocline at $15 \mathrm{~m}$ depth was apparent at Rasiyah on $19^{\text {th }}$ October, and below this depth temperature declined from $26.2^{\circ} \mathrm{C}$ to $21.6^{\circ} \mathrm{C}$ at $25 \mathrm{~m}$ depth (Table 1, Fig. 6). DO likewise declined from $6.57 \mathrm{ml} / \mathrm{L}$ at $15 \mathrm{~m}$ depth to $0.82 \mathrm{ml} / \mathrm{L}$ at $25 \mathrm{~m}$. Similar temperature and DO profiles (minimum DO of $1.3 \mathrm{ml} / \mathrm{L}$ at $20 \mathrm{~m}$ ) occurred at Al-Aigah, although the 


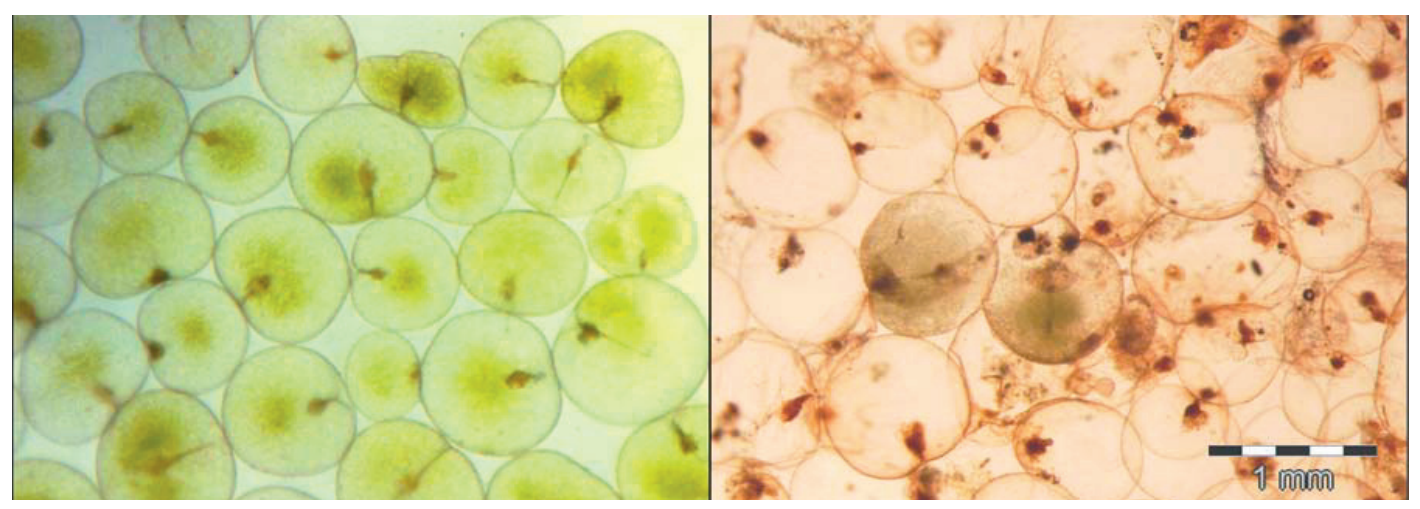

Figure 2. Phytoplankton (Noctiluca scintillans) when alive (green) and while decaying (red) found in the Masirah Island Red Tide.

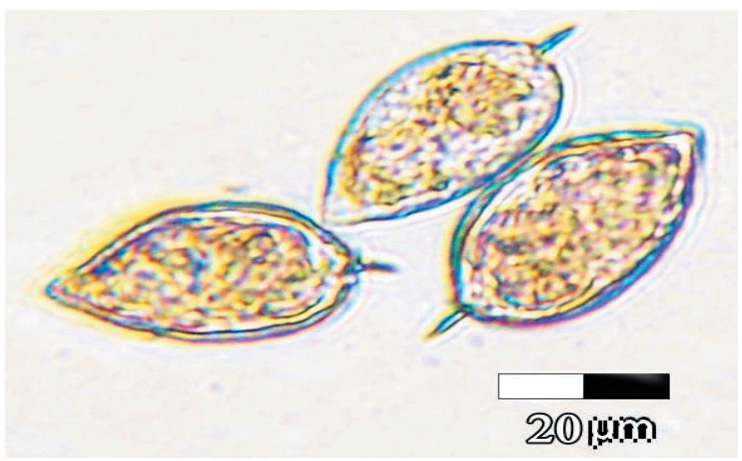

Figure 3. Phytoplankton (Prorocentrum micans) found in Masirah Island Red Tide.

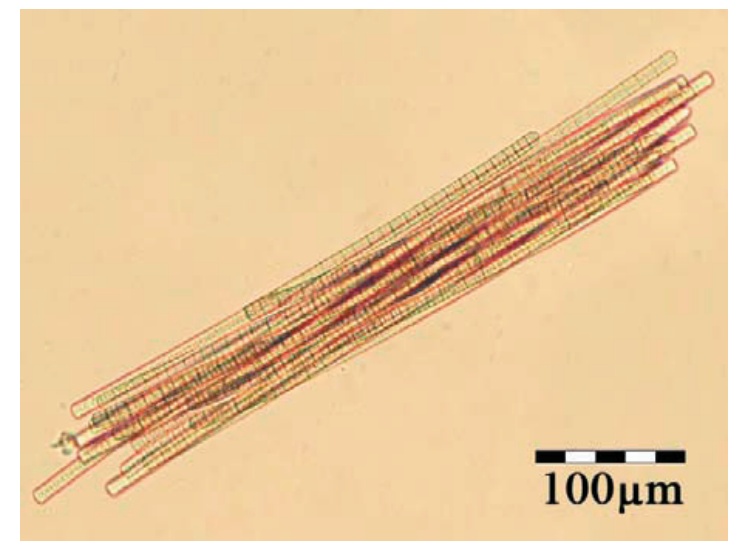

Figure 4. Phytoplankton (Trichodesmium erythraeum) found in Masirah Island Red Tide. 


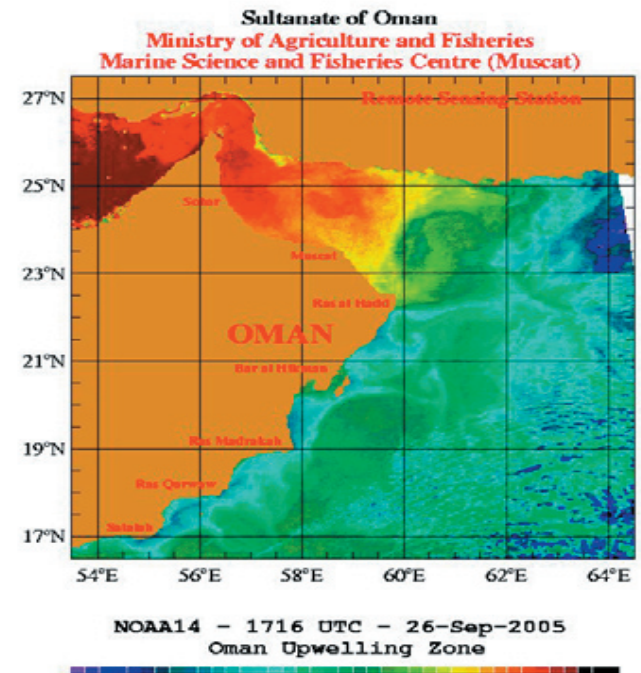

$\begin{array}{llllllllllllllllll}15 & 16 & 17 & 18 & 19 & 20 & 21 & 22 & 23 & 24 & 25 & 26 & 27 & 28 & 29 & 30 & 31 & 32\end{array}$ Sea Surface Temperature $\left({ }^{\circ} \mathrm{C}\right)$

Sea surface temperature (26th September 2005)

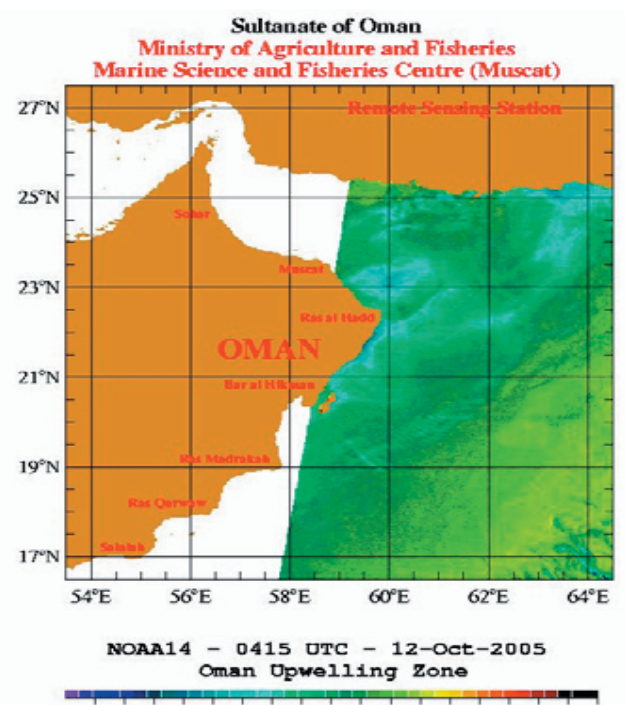

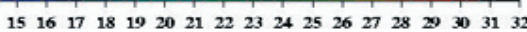
Sea Surface Temperature $\left({ }^{\circ} \mathrm{C}\right)$

Sea surface temperature (12 October 2005)

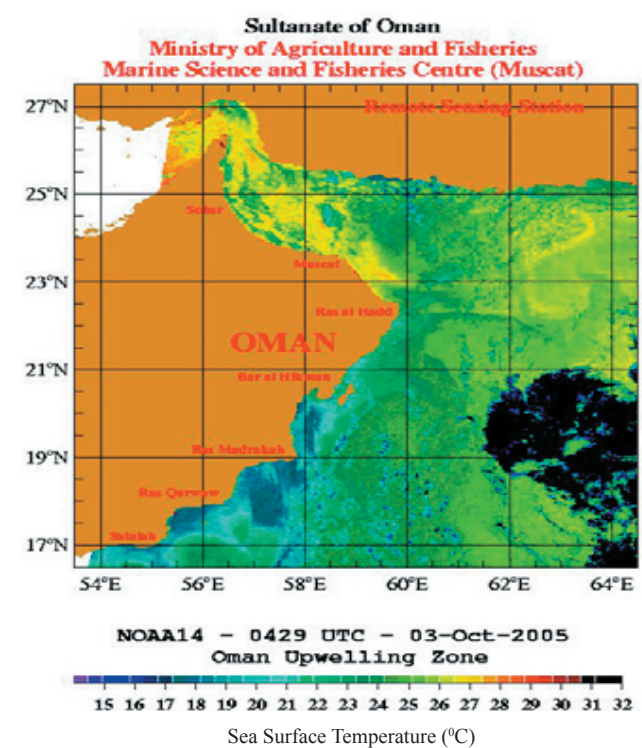

Sea surface temperature (3rd October 2005)

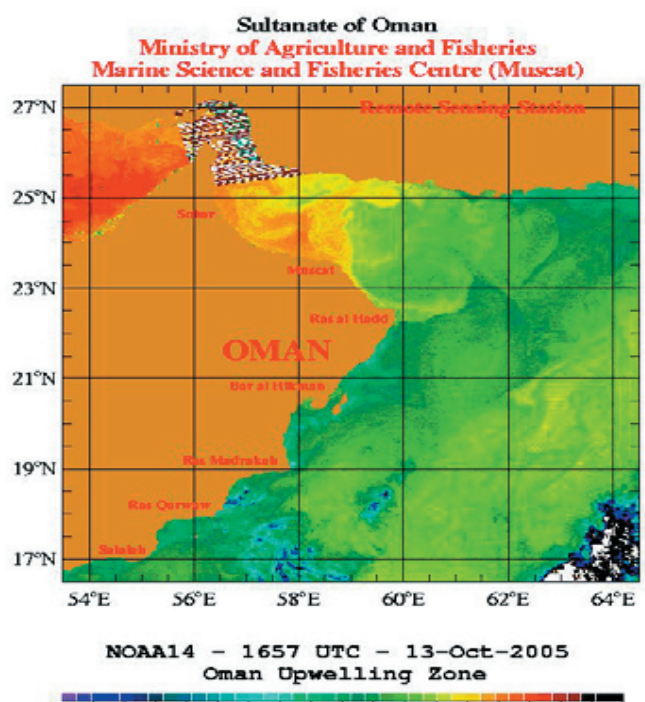

$\begin{array}{llllllllllllllllll}15 & 16 & 17 & 18 & 19 & 20 & 21 & 22 & 23 & 24 & 25 & 26 & 27 & 28 & 29 & 30 & 31 & 32\end{array}$ Sea Surface Temperature $\left({ }^{\circ} \mathrm{C}\right)$

Sea surface temperature (13th October 2005)

Figure 5. Satellite images show the variation in temperature before, during and after the Red tide blooms in Arabian Sea (Oman upwelling zone).

Source of images: Remote Sensing Station at Ministry of Fisheries Wealth, (Satellite NOAA 14). 
Table 1. Temperature (Temp), Dissolved Oxygen (DO), Salinity (Sal.) and pH during Red tide bloom.

\begin{tabular}{|c|c|c|c|c|c|c|c|c|}
\hline \multirow[b]{2}{*}{ Location } & \multirow[b]{2}{*}{ Date/ Time } & \multirow{2}{*}{$\begin{array}{l}\text { Distance } \\
\text { from shore }\end{array}$} & \multirow{2}{*}{$\begin{array}{l}\text { Latitude/ } \\
\text { Longitude }\end{array}$} & \multirow{2}{*}{$\begin{array}{r}\text { Depth } \\
\text { (m) }\end{array}$} & \multicolumn{4}{|c|}{ Ecological Parameters } \\
\hline & & & & & $\begin{array}{r}\text { Temp } \\
\left({ }^{\circ} \mathrm{C}\right) \\
\end{array}$ & $\begin{array}{r}\text { DO } \\
(\mathrm{ml} / \mathrm{l})\end{array}$ & $\begin{array}{r}\text { Sal. } \\
(\%)\end{array}$ & pH \\
\hline \multirow[t]{4}{*}{ Al-Aigah } & $19 / 10 / 2005$ & $2 \mathrm{~km}$ & $20^{\circ} 34^{\prime} 13 \mathrm{~N}$ & 0 & 26.15 & 7.11 & 36.58 & 7.95 \\
\hline & $7: 10 \mathrm{am}$ & & $58^{\circ} 59^{\prime} 11 \mathrm{E}$ & 5 & 26.08 & 6.83 & 36.64 & 8.00 \\
\hline & & & & 15 & 24.02 & 3.44 & 36.70 & 7.78 \\
\hline & & & & 20 & 22.07 & 1.30 & 36.65 & 7.68 \\
\hline \multirow[t]{6}{*}{ Rasia } & $19 / 10 / 2005$ & $2 \mathrm{~km}$ & $20^{\circ} 31^{\prime} 24 \mathrm{~N}$ & 0 & 26.44 & 6.40 & 36.64 & 8.04 \\
\hline & $8: 00 \mathrm{am}$ & & $59^{\circ} 00^{\prime} 29 \mathrm{E}$ & 5 & 26.29 & 6.42 & 36.66 & 8.09 \\
\hline & & & & 10 & 26.18 & 6.35 & 36.65 & 8.13 \\
\hline & & & & 15 & 26.15 & 6.57 & 36.65 & 8.16 \\
\hline & & & & 20 & 23.64 & 3.40 & 36.68 & 7.89 \\
\hline & & & & 25 & 21.61 & 0.82 & 36.60 & 7.66 \\
\hline
\end{tabular}

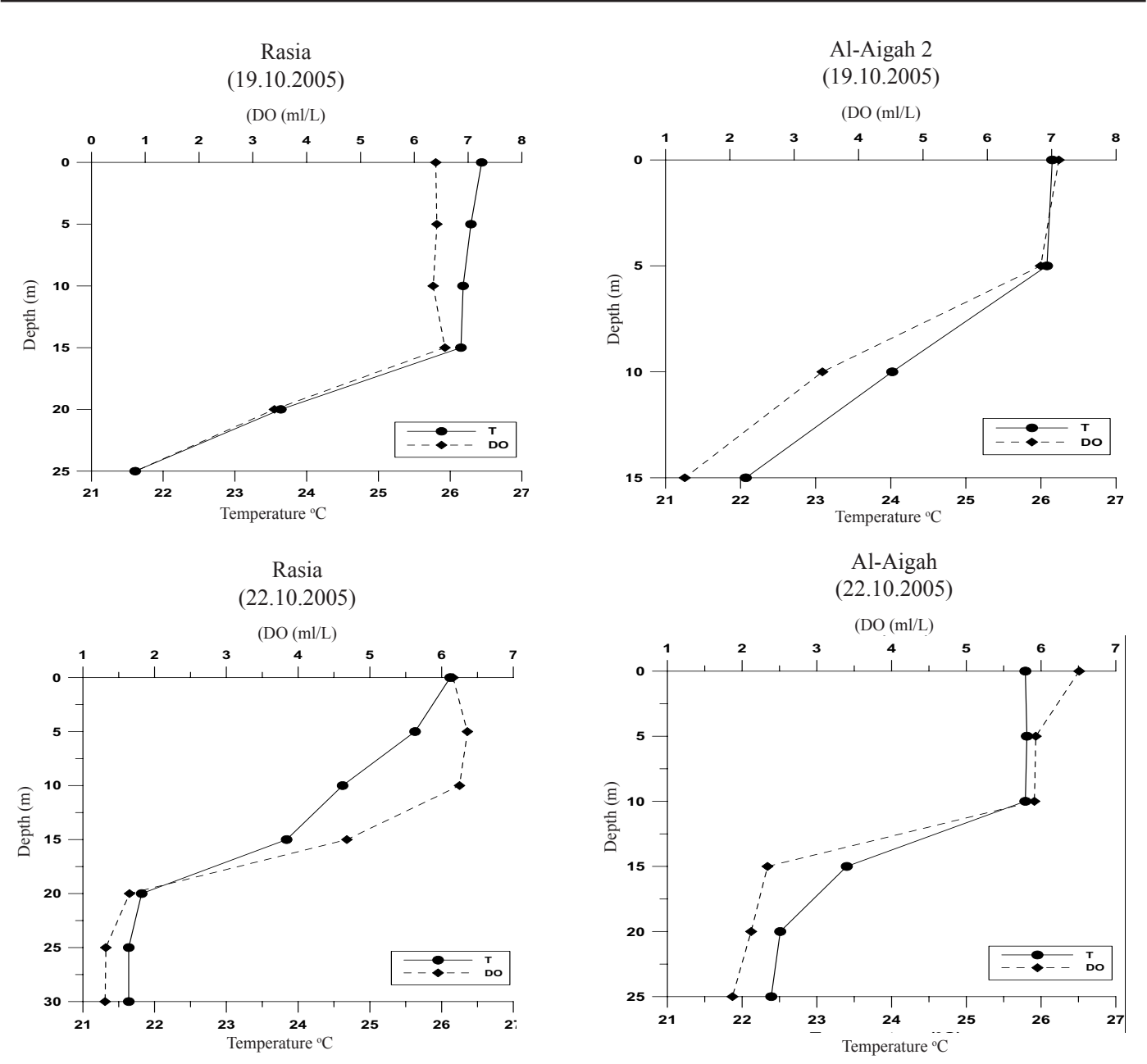

Figure 6. Show the relation between depth, Dissolved Oxygen (DO) and Temperature (T), during and after red tide in two stations. 
Table 2. Temperature (Temp), Dissolved Oxygen (DO), Salinity (Sal.) and pH after Red tide Bloom in two stations after red tide blooms.

\begin{tabular}{|c|c|c|c|c|c|c|c|c|}
\hline \multirow[b]{2}{*}{ Location } & \multirow{2}{*}{$\begin{array}{l}\text { Date/ } \\
\text { Time }\end{array}$} & \multirow{2}{*}{$\begin{array}{l}\text { Distance } \\
\text { from shore }\end{array}$} & \multirow{2}{*}{$\begin{array}{l}\text { Latitude/ } \\
\text { Longitude }\end{array}$} & \multirow{2}{*}{$\begin{array}{l}\text { Depth } \\
\text { (m) }\end{array}$} & \multicolumn{4}{|c|}{ Ecological Parameters } \\
\hline & & & & & $\begin{array}{c}\text { Temp } \\
\left({ }^{\circ} \mathrm{C}\right) \\
\end{array}$ & \begin{tabular}{|c|} 
DO \\
$(\mathrm{ml} / \mathrm{l})$ \\
\end{tabular} & $\begin{array}{l}\text { Sal. } \\
(\%)\end{array}$ & pH \\
\hline \multirow[t]{6}{*}{ Al-Aigah } & $22 / 10 / 05$ & $2 \mathrm{~km}$ & $20^{\circ} 35^{\prime} 19 \mathrm{~N}$ & 0 & 25.79 & 6.51 & 36.61 & 7.95 \\
\hline & $7: 10 \mathrm{am}$ & & $58^{\circ} 57^{\prime} 11 \mathrm{E}$ & 5 & 25.81 & 5.93 & 36.66 & 8.04 \\
\hline & & & & 10 & 25.79 & 5.91 & 36.67 & 8.07 \\
\hline & & & & 15 & 23.40 & 2.34 & 36.62 & 7.82 \\
\hline & & & & 20 & 22.51 & 2.12 & 36.58 & 7.80 \\
\hline & & & & 25 & 22.39 & 1.87 & 36.57 & 7.79 \\
\hline \multirow[t]{7}{*}{ Rasia } & $22 / 10 / 05$ & $2 \mathrm{~km}$ & $20^{\circ} 31^{\prime} 01 \mathrm{~N}$ & 0 & 26.12 & 6.16 & 36.62 & 8.08 \\
\hline & 8:00 am & & $58^{\circ} 59^{\prime} 29 \mathrm{E}$ & 5 & 25.63 & 6.36 & 36.65 & 8.11 \\
\hline & & & & 10 & 24.62 & 6.25 & 36.60 & 8.12 \\
\hline & & & & 15 & 23.84 & 4.68 & 36.59 & 8.02 \\
\hline & & & & 20 & 21.82 & 1.65 & 36.58 & 7.79 \\
\hline & & & & 25 & 21.64 & 1.32 & 36.57 & 7.77 \\
\hline & & & & 30 & 21.64 & 1.31 & 36.59 & 7.78 \\
\hline
\end{tabular}

thermocline appears to have been shallower at 5-10 m depth (Table 1, Fig. 6). A marginal increase in DO was seen at both sites on the $22^{\text {nd }}$ of October - at Rasiyah the $\mathrm{DO}$ at $25 \mathrm{~m}$ depth had increased from 0.82 to 1.32 $\mathrm{ml} / \mathrm{L}$, and at Al-Aigah the increase at $20 \mathrm{~m}$ depth was from 1.3 to $2.12 \mathrm{ml} / \mathrm{L}$ (Table 2, Fig. 6). Salinity and $\mathrm{pH}$ profiles were similar on $19^{\text {th }}$ and $22^{\text {nd }}$ October, with salinity remaining between $36.57 \%$ and $36.70 \%$ irrespective of depth, and $\mathrm{pH}$ fluctuating between 7.66 and 8.16 (Fig. 7).

Dead and weakened fish and invertebrates were observed on or near the surface of the water and along the tide line on the shore. Fishers caught larger than usual quantities of jobfishes (Lutjanidae) and remarked that the fish seemed lethargic, easier to catch than usual, and were schooling. Large numbers of swimming crabs (Portunidae) were observed in surface layers. We identified Lutjanids, Sciaenids, Carangids, Lethrinids and Sparids among the dead fishes. Most of these families form part of the demersal assemblage in coastal waters (Al-Abdessallaam, 1995). Samples of dead fish analyzed for presence of bacteria showed that none of the samples were infected with colioforms, E. coli, Salmonella, Shigella, Vibrios, Staphilococcus aureus, Cyanobacter, Bacillus cereus, Clostridium, or Listeria monocytogenes. These fish were therefore safe for human consumption, and fisherman who continued to consume the fish during the red tide event did not report any adverse reaction.

Most demersal fish species require a DO of at least $2 \mathrm{ml} / \mathrm{L}$ (Al Gheilani, 2007) to survive, and the DO levels of $<1.4 \mathrm{ml} / \mathrm{L}$ below $15 \mathrm{~m}$ depth at both sites are unlikely to sustain some species over an extended period. Therefore stress induced by low oxygen conditions below the thermocline may have been the cause of mortalities where fish could not move away. Fish that could move away may have been displaced from their habitat, but the effects of this on their condition can only be surmised. The low oxygen conditions were apparently the result of blooms and collapse of the dinoflagellates $P$. micans and $N$. scintillans and the cyanobacterium T. erythraeum following on a series of upwelling events with nutrient enrichment of surface waters. The breakdown of the thermocline during such upwelling, and the mixing that brings cooler nutrient-rich waters to the surface layers can be caused by wind forcing or lower air temperatures during fall or winter (Lindell and Post, 1995; Genin et al., 1995). No cell counts of the three predominant phytoplankters were done, and it is therefore difficult to rule out poisoning of fish by toxins released by $T$. erythraeum. Nevertheless, most 


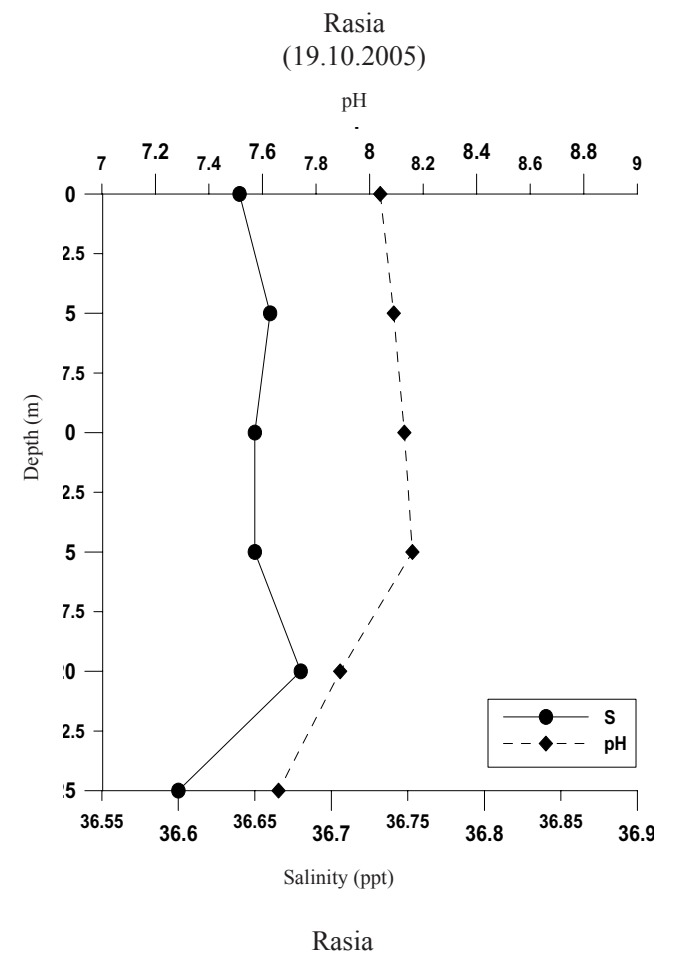

$(22.10 .2005)$

$\mathrm{pH}$

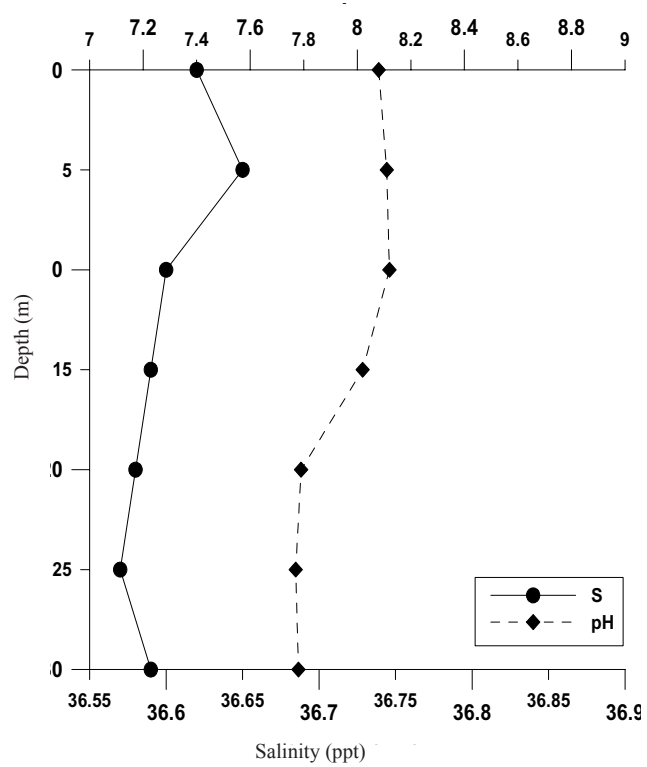

Al-Aigah 2

$(19.10 .2005)$

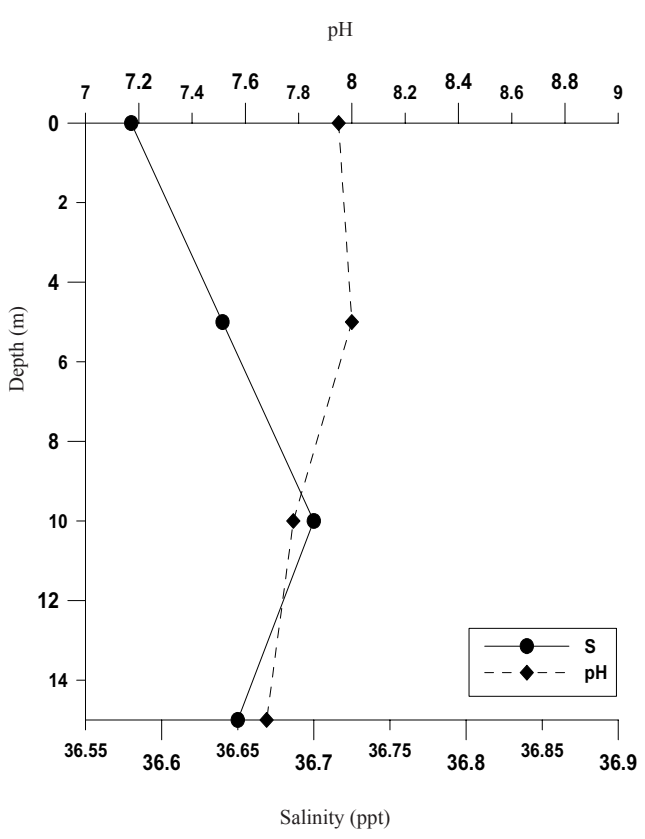

Al-Aigah

$(22.10 .2005)$

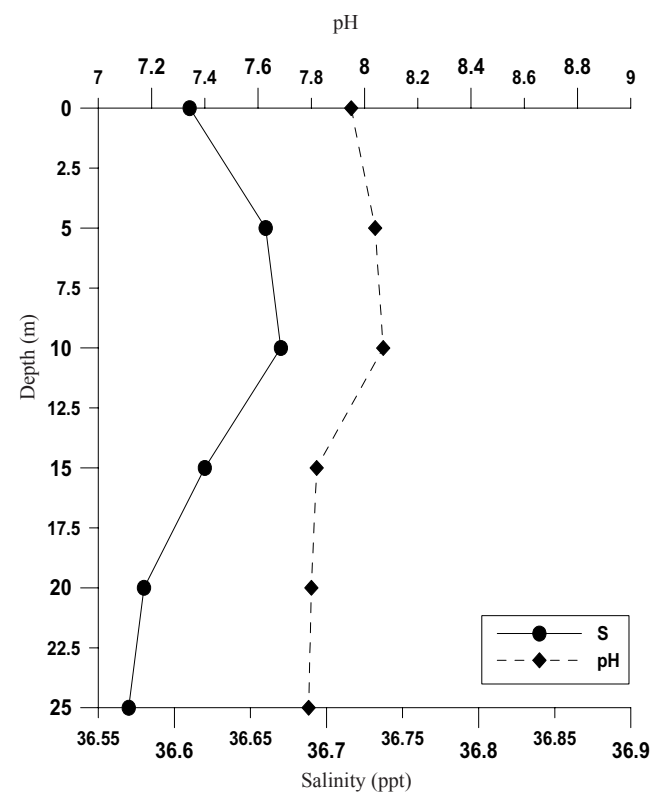

Figure 7. Show the relation between depth, $\mathrm{pH}$ and Salinity, during and after red tide in two stations. 
evidence points to low oxygen conditions below the thermocline during the red tide event as an indirect cause of fish mortalities.

\section{Acknowledgments}

We thank Ahmed Al-Aisry and Hilal Al-Shaqsi from the Marine Ecology Laboratory at the Marine Science and Fisheries Centre, Ministry of Fisheries Wealth for providing Satellite Images and Hydrolab data. Thanks are also due to the staff of Fisheries Directory at AlWusta Region for providing facilities during the red tide occurrence.

\section{References}

Al-Abdessalaam, T.Z.S. 1995. Marine Species of the Sultanate of Oman: An Identification Guide. Marine Science and Fisheries Centre, Ministry of Fisheries and Agriculture, Muscat Printing Press ( $1^{\text {st }}$ ed.), $412 \mathrm{pp}$.

Al-Gheilani, H.M. 2007. Physiological and Biochemical Effects of Hypoxia Exposure on Goldlined Seabream, Rhabdosargus sarba. Ph.D. thesis, Portsmouth University, UK.

Anderson, D.M., G.M. Gilbert and J.M. Burkholder. 2002. Harmful algal blooms and eutrophication: Nutrient sources, composition, and consequences. Estuaries, 25(4b):704-726.

Capone, D.G., A. Subramaniam, J.P. Montoya, M. Voss, C. Homborg, A.M. Johansen, Q. Wang, H. $\mathrm{Li}$, and F. Post. 2000. The nitrate assimilation genes of the marine diazotrophic cyanobacterium 'Trichodesmium' sp. strain WH9601. Journal of Bacteriology, 182:1764-1767.

Claereboudt, M., G. Hermosa, and E. McLean. 2001. Plausible cause of massive fish kills in the Gulf of Oman. In: Proceedings of the First International Conference of Fisheries, Aquaculture and Environment in the $N W$ Indian Ocean, M. Claereboudt, S. Goddard, H. Al-Oufi, E. McIlwain (Editors), 123-132. Sultan Qaboos University, Muscat, Sultanate of Oman.

Endean, R., S.A. Monks, J.K. Griffith and L.E. Llewellyn, 1993. Apparent relationship between toxins elaborated by the cynaobacterium Trichodesmium erythraeum and those present in the flesh of the narrow-barred Spanish mackerel Scomberomorus commersoni Journal of Toxicology, 9:1155-1165.

Genin, A., B. Lazar and S. Brenner, 1995. Vertical mixing and coral death in the Red Sea following the eruption of Mount Pinatubo. Journal of Nature, 377:507-510.

Lindell, D. and A.F. Post. 1995. Ultraphytoplankton succession is triggered by deep water mixing in the Gulf of Aqaba (Eilat) Red Sea. Limnol. Journal of Oceanography, 40:1130-1141.

Lowe, J.A., D.R.G. Farrow, A.S. Pait, S.J. Arenstam, and E.J. Lavan. 1991. Fish kills in coastal waters 1980-1989. National Oceanographic and Atmospheric Administration, 69pp.

Okaichi, T. and S. Nishio. 1976. Identification of ammonia as the toxic principle of red tide of Noctiluca miliaris. Bulletin of Plankton Society, Japan, 23:75-80.

Ohki, K., J.P. Zehr, P.G. Fallowski, and Y.Fiujita. 1991. Regulation of nitrogen fixation by different nitrogen sources in the marine non-heterocystous cyanobacterium Trichodesmium sp. NBB1067. Journal of Archeology and Microbiology, 156: 335-337.

Post, A.E., Z. Dedej, R. Gottlieb, D.N. Thomas, M. ElAbsawi, A. El-Naggar, M. El-Gharabawi, and U. Sommer. 2002. Spatial and temporal distribution of Trichodesmium spp. in the stratified Gulf of Aqaba, Red Sea. Marine Ecological Progress Series, 239:241-250.

Subba Rao, D.V., Y. Pan, and S.J. Smith. 1995. Allebopathy between Rhizosolenia alata (Brightwell) and the toxigenic Pseudnitzchia pungens f. multiseries. In: Harmful Marine Algal Blooms, P. Lassus, G. Arzul, E. Erard-Le Deen, P. Gentien and C. Marcaillon-Le-Baut, (Editors), 329-334. Paris, Lavoiser.

Thangraja, M., A. Al-Aisri, and H. Al-Shaqsi. 2000. Phytoplankton Blooms, Red Tide Phenomena and Recorded Impacts in Oman. Marine Science and Fisheries Center Annual Report, Ministry of Agriculture and Fisheries, Sultanate of Oman, 22pp.

Velikova, V. and J. Larsen. 1999. The Prorocentrum cordatum/Prorocentrum minimum taxonomic problem. Grana 38:108-112. 